\title{
PUBLIC REASON AND RELIGION: THE THEO-ETHICAL EQUILIBRIUM ARGUMENT FOR RESTRAINT
}

\author{
(Accepted 24 April 2017)
}

\begin{abstract}
Most public reason theorists believe that citizens are under a 'duty of restraint'. Citizens must refrain from supporting laws for which they have only non-public reasons, such as religious reasons. The theo-ethical equilibrium argument purports to show that theists should accept this duty, on the basis of their religious convictions. Theists' beliefs about God's nature should lead them to doubt moral claims for which they cannot find secular grounds, and to refrain from imposing such claims upon others. If successful, this argument would defuse prominent objections to public reason liberalism. This paper assesses the theoethical equilibrium argument, with a specific focus on Christian citizens. I argue that Christians should seek theo-ethical equilibrium, but need not endorse the duty of restraint. I establish this in part through examining the important theological concept of natural law. That discussion also points to more general and persistent problems with defining 'public reasons'.
\end{abstract}

Public reason liberals believe that, in order to be legitimate, laws must be justified by 'public reasons' - reasons that are in some sense acceptable to, accessible to, or shareable by all reasonable citizens. ${ }^{1}$ Most further believe that ordinary citizens are under a 'duty of restraint'. Citizens should offer public reasons for laws and refrain from supporting laws for which their only reasons are non-public. ${ }^{2}$ Religious reasons - reasons that are grounded in a religious doctrine and only have normative force for those who accept that doctrine ${ }^{3}-$

\footnotetext{
${ }^{1}$ This characterisation deliberately excludes the 'convergence conception' endorsed by Gerald Gaus and Kevin Vallier. This paper focuses exclusively on the consensus conception.

${ }^{2}$ Rawls's 'duty of civility' is an example. John Rawls, Political Liberalism, expanded edition (New York: Columbia University Press, 2005), pp. 444-445.

${ }^{3}$ For discussion of what makes a reason 'religious', see Robert Audi, Democratic Authority and the Separation of Church and State (New York: Oxford University Press, 2011), pp. 72-73; Nicholas C. Bamforth and David A. J. Richards, Patriarchal Religion, Sexuality, and Gender: A Critique of New Natural Law (Cambridge: Cambridge University Press, 2008), pp. 46-52.
} 
are often seen as archetypal non-public reasons. Citizens should thus refrain from supporting laws for which they have only religious justification.

Critics have argued that this requirement creates 'conflicts of loyalty' for religious citizens. A citizen might believe that she is obligated to support a law for which she has only religious reasons. Failure to support this law would violate her perceived duties to God. Supporting the law, however, would violate her duty of restraint. Some have argued that the fact it gives rise to these kinds of conflicts is reason to reject the duty of restraint, ${ }^{4}$ and thus to reject public reason liberalism (hereinafter 'PRL'). ${ }^{5}$

Conflicts of loyalty would never arise, however, if citizens' religious beliefs themselves decisively supported the duty of restraint, such that PRL never requires believers to do anything that they lack existing theological reasons to do. Some theorists have argued that this is in fact the case. Religious citizens have theological reason to refrain from supporting laws for which their only arguments are religious.

The 'theo-ethical equilibrium' argument is an example. ${ }^{6}$ According to this argument, God's nature is such that theists should expect all important moral truths ${ }^{7}$ to have sound secular rationales. ${ }^{8}$ They should thus seek to achieve 'theo-ethical equilibrium', a reflective equilibrium reconciling secular and religious sources of moral knowledge. Religiously-grounded moral beliefs that lack any secular rationale, so are not within theo-ethical equilibrium, should be doubted. Theists' confidence in such beliefs should be lower than is necessary to justify imposing them upon others through law.

\footnotetext{
${ }^{4}$ Christopher J. Eberle, Religious Conviction in Liberal Politics (Cambridge: Cambridge University Press, 2002), pp. 140-148; Nicholas Wolterstorff, 'The Role of Religion in Decision and Discussion of Political Issues', in Robert Audi and Nicholas Wolterstorff, Religion in the Public Square: The Place of Religious Convictions in Political Debate (London: Rowman \& Littlefield, 1997), pp. 67-120; Micah Lott, 'Restraint on Reasons and Reasons for Restraint: A Problem for Rawls's Ideal of Public Reason', Pacific Philosophical Quarterly 87(1) (2006), pp. 75-95.

${ }^{5}$ Others argue that we can endorse PRL while rejecting the duty of restraint for ordinary citizens. Jürgen Habermas, 'Religion in the Public Sphere', European Journal of Philosophy 14(1) (2006), pp. 1-25; Cécile Laborde, 'Justificatory Secularism', in Gavin D’Costa, Malcolm Evans, Tariq Modood, and Julian Rivers (eds.), Religion in a Liberal State (Cambridge: Cambridge University Press, 2013), pp. 164-186. In this paper I assume that restraint is a constitutive part of PRL.

${ }^{6}$ For another example, see Kyle Swan, 'Can a Good Christian be a Good Liberal?', Public Affairs Quarterly 20(2) (2006), pp. 163-173.

${ }^{7}$ I follow Eberle (Religious Conviction, p. 397, n. 3) in using 'moral claim' to refer to moral propositions, and 'moral truth' to refer to true moral propositions.

${ }^{8}$ Throughout this paper, 'secular' reasons and rationales are those that do not assume the truth of any religious beliefs or rely on religious beliefs for their justificatory force.
} 
This paper assesses the theo-ethical equilibrium argument for restraint (hereinafter 'the TEE argument'), with a focus on Christianity. While some of my arguments might apply for all theists, I also consider specifically Christian theological ideas. This is appropriate in assessing the TEE argument. The argument appeals to theology, so its success will depend on the theological resources within a particular religion. I will argue that Christians should indeed seek theo-ethical equilibrium, but need not endorse the duty of restraint.

The paper unfolds as follows. Section I explains the TEE argument and its relationship to PRL in more detail. Sections II and III present two objections to the argument. In Section IV I consider Christian views of natural law, since this is the theological doctrine that is most relevant to the TEE argument. I argue that while a 'high view' of natural law appears to support the argument for restraint, a more plausible 'moderate view' does not. This reinforces the objections presented in Sections II and III. Section V revisits the relationship between the high view and restraint. I argue that the apparent coherence does not withstand scrutiny, and that this points to more general and persistent problems with defining 'public reasons'.

If it were successful, the TEE argument would be highly significant to debates concerning religion and public justification, since it would show that complaints about the duty of restraint from Christian citizens are mistaken. Its failure means that those complaints - and thus a prominent strain of objections to PRL - remain. Further, many public reason liberals hold that endorsement of the duty of restraint is a criterion for reasonableness. My argument therefore suggests that it remains an open question on what basis Christians, given their theological resources, can join the overlapping consensus of reasonable citizens.

\section{THE THEO-ETHICAL EQUILIBRIUM ARGUMENT}

Robert Audi and Michael Perry both argue that, given their beliefs about God's nature, Christians should expect to find non-religious grounds for moral truths. ${ }^{9}$ God is omniscient, omnipotent and

\footnotetext{
${ }^{9}$ Robert Audi, 'Liberal Democracy and the Place of Religion in Politics', in Audi and Wolterstorff, Religion in the Public Square, pp. 1-66, at pp. 9-24; Michael J. Perry, Religion in Politics: Constitutional and Moral Perspectives (Oxford: Oxford University Press, 1997), pp. 72-82; Michael J. Perry, Under God? Religious Faith and Liberal Democracy (Cambridge: Cambridge University Press, 2003), pp. 55-85.
} 
omnibenevolent. He knows all moral truths, and wants everyone, even the non-religious, to fulfil their moral obligations. Individuals can only fulfil their obligations (over the long term) if they know what those obligations are, which requires that they have access to sound arguments for the relevant moral truths. Since not everyone has access to religious sources of moral truth, Christians should expect God to have structured the world such that there are adequate secular grounds for those truths - grounds accessible to all. 'We should expect there to be accessible, adequate, secular reasons for major moral principles'. ${ }^{10}$

It is unclear precisely what is meant by the claim that not everyone has 'access' to religious sources of moral knowledge. Christopher Eberle interprets it to refer to the fact that no sacred texts, the primary sources of religious truth, are available to everyone. ${ }^{11}$ For each sacred text, there are some individuals who cannot access it, no matter how earnestly they try. A different interpretation, which might be closer to Audi's and Perry's intentions, is that all non-religious individuals lack 'access' to all religious sources of moral truth, because they do not accept the fundamental premises on which they are based. The issue is epistemic inaccessibility, rather than the physical inaccessibility of Scripture. Even those with access to Scripture lack access to moral truths contained within it, because they do not accept its veracity or authority. God desires individuals who reject the authority of religious sources of moral insight to fulfil their moral obligations, and will therefore have provided secular paths to moral truths.

On either interpretation, the vital point is that there will be adequate non-religious arguments for moral truths. 'Religiously grounded moral truths will likely be corroborable by adequate secular grounds. ${ }^{12}$ Secular ethical considerations are thus relevant to discovering what God wants us to do. Christians should pay attention to them, and seek to harmonise religious and secular moral insights. As Audi writes, 'civic virtue on the part of the religious should embody a commitment to theo-ethical equilibrium - a rational integration between religious deliverances and insights and, on the other hand, secular ethical considerations'. ${ }^{13}$ This can be understood

\footnotetext{
${ }^{10}$ Audi, 'Liberal Democracy', p. 19.

${ }^{11}$ Eberle, Religious Conviction, pp. 301-302.

${ }^{12}$ Ibid., p. 302.

${ }^{13}$ Audi, 'Liberal Democracy', p. 21.
} 
as a kind of reflective equilibrium. One seeks to achieve a coherent set of beliefs (including both general principles and judgments on specific cases) based on all relevant evidence. ${ }^{14}$

Further, Christians should accept that their religiously-grounded moral beliefs can be mistaken. Since all moral truths have secular grounds, a lack of secular corroboration for a religiously-grounded moral claim constitutes evidence against it. Christians should doubt such claims, which are not within theo-ethical equilibrium. Precisely how much doubt this casts upon the claim - whether one should consider it refuted or merely lower one's confidence in it, and by what degree - is unclear. What is clear, for Audi and Perry, is that one's confidence in the claim should be lower than is necessary to justify coercively imposing it upon others. Audi thus concludes that 'a mature, conscientious theist... should be reluctant or unwilling to support coercive laws or public policies on a religious basis that cannot be placed in [theo-ethical] equilibrium'. ${ }^{15}$ Perry concurs: 'no religious argument about the requirements of human well-being should be deemed sufficiently strong to ground a political choice, least of all a coercive political choice, unless a persuasive secular argument reaches the same conclusion'. ${ }^{16}$

This argument, if sound, gives Christians theological reasons to accept a core aspect of PRL's duty of restraint. Specifically, Christians should not support laws for which their only reasons are religious. They should only support laws when they have, and are willing to offer, secular reasons. Importantly, this duty is grounded in theology. Christians' religious beliefs themselves require that they seek to unite religious and secular insights, and doubt religiously-grounded moral claims that lack secular corroboration. Abiding by the duty of restraint does not involve dividing one's beliefs into 'religious' and 'secular' perspectives, living one's private life on the basis of the former but acting politically on the basis of the latter. Instead, abiding by that duty is itself a way to conform one's political actions to one's religious beliefs.

\footnotetext{
${ }^{14}$ Audi, Democratic Authority, pp. 20-25, connects theo-ethical with reflective equilibrium. This is not necessarily reflective equilibrium in the specifically Rawlsian sense of using a theoretical device like the original position to achieve coherence between a set of principles and one's considered convictions.

${ }^{15}$ Audi, 'Liberal Democracy', p. 21.

${ }^{16}$ Perry, Religion in Politics, p. 73.
} 
Whether the duty of restraint justified by the TEE argument fully matches the duties placed on citizens by PRL depends on the version of PRL in view. ${ }^{17}$ For Audi, laws should be justified by secular reasons, and citizens should only support laws when they have such reasons. ${ }^{18}$ His preferred version of restraint thus seems to fully cohere with the duty justified by the TEE argument.

Matters are less straightforward with regard to Rawls's view. According to Rawls's 'duty of civility', citizens should only support laws that are justified by the values and principles contained within a reasonable political conception of justice. Such a conception is 'political' in three senses: its principles 'apply to basic political and social institutions'; it 'can be presented independently from comprehensive doctrines of any kind'; and it can be worked out from ideas 'implicit in [society's] public political culture'. ${ }^{19}$ Engaging in public reason involves appealing to such a conception 'when debating fundamental political questions'. ${ }^{20}$ Importantly, this means that not all 'secular reasons' are 'public reasons'. ${ }^{21}$ Reasons grounded in non-religious comprehensive doctrines are secular but non-public. More generally, Rawlsian public reason liberals tend to define public reasons as reasons that all citizens can reasonably be expected to accept reasons that are accessible to, or shareable by, all citizens, such that all can acknowledge their normative force. ${ }^{22}$ Some reasons are secular and yet sectarian, and thus non-public. In some cases, the duty of restraint justified by the TEE argument will come apart from the duties imposed by Rawlsian PRL. Christians might find reasons for a law that are secular but non-public. The TEE argument would permit the advocacy of such a law, while Rawlsians would not.

Nonetheless, the gap between the TEE argument and Rawlsian PRL should not be overstated. All Rawlsian public reason liberals impose a duty not to support laws for which one's only reasons are religious. The TEE argument justifies this core element of the duty of restraint. This element of the duty has been the focus of much of the critical discussion of PRL, since it seemingly gives rise to conflicts

\footnotetext{
17 Thanks to an anonymous reviewer for pressing me to clarify this point.

${ }^{18}$ Audi, 'Liberal Democracy', pp. 24-28; Audi, Democratic Authority, pp. 65-70.

${ }^{19}$ Rawls, Political Liberalism, p. 453.

${ }^{20}$ Ibid.

${ }^{21}$ Ibid., pp. 452, 457-458

22 Ibid., p. 217; Kevin Vallier, Liberal Politics and Public Faith: Beyond Separation (Oxford: Routledge, 2014), pp. 108-110.
} 
of loyalty, in cases where citizens believe that laws are morally required solely for religious reasons. If sound, the TEE argument dissolves such conflicts, by showing that such citizens have theological reasons to doubt the relevant moral claim, and to refrain from seeking its coercive imposition. Loyalty to God itself mandates restraint. The success of the TEE argument would be a significant step toward PRL and rebut a prominent objection to restraint, even if a gap between the implications of the TEE argument and Rawlsian versions of PRL remains.

Further, Christians are unlikely to reach theo-ethical equilibrium using secular reasons grounded in a non-religious comprehensive doctrine, since they would reject that doctrine in favour of their Christian comprehensive doctrine. The secular reasons for laws that Christians find persuasive, and are thus contained in theo-ethical equilibrium, are likely to usually be Rawlsian public reasons. I consider examples where this isn't the case, and discuss the implications of this for the relationship between the TEE argument and PRL, in Section V.

A different worry about the level of congruence between the TEE argument and PRL is that the argument justifies restraint for the wrong kinds of reasons. ${ }^{23}$ The TEE argument focuses on epistemic claims regarding the confidence with which one ought to hold moral beliefs, whereas PRL is about the normative ideal of justifying the terms of social cooperation using reasons acceptable to all, despite reasonable pluralism.

While there is something to this worry, the difference here should not be exaggerated. The TEE argument is not purely epistemic; it requires a normative premise that respect for one's compatriots requires that one only seek to impose laws that are sufficiently welljustified. PRL, meanwhile, requires epistemic premises concerning the reasonableness of pluralism. For example, Rawls appeals to the burdens of judgment, which are at least partially epistemic. ${ }^{24}$ Some theorists place great emphasis on the epistemic elements of PRL. ${ }^{25}$

Further, even if (most) public reason liberals justify the duty of restraint (primarily) on normative grounds, they should be open to

\footnotetext{
${ }^{23}$ Thanks to an anonymous reviewer for pressing me to consider this point.

${ }^{24}$ Rawls, Political Liberalism, pp. 54-58.

${ }^{25}$ For example, Fabienne Peter, 'Epistemic Foundations of Political Liberalism', Journal of Moral Philosophy 10(5) (2013), pp. 598-620.
} 
the duty's compatibility with Christianity being shown using a (primarily) epistemic argument. Public reason liberals want citizens to accept PRL for whatever reasons they find within their comprehensive doctrines. This is part of what Rawls calls 'full justification' ${ }^{26}$ Even if PRL itself is not tied to any particular epistemic doctrine, if Christians' best epistemic account leads them to accept the duty of restraint then this is something that public reason liberals should embrace, since it helps to show how Christians can be part of the overlapping consensus. Of course, the TEE argument does not justify PRL as a whole; it merely justifies a core element of the duty of restraint. Further normative arguments are needed to show that Christians can accept other aspects of PRL. Nonetheless, the TEE argument is important precisely because it seeks to justify one of the most contentious implications of PRL for religious citizens.

\section{INITIAL ASSESSMENT}

Many of the TEE argument's premises are plausible. Audi and Perry are correct to emphasise that Christian citizens should pay attention to secular moral arguments. Christians believe that reason is a gift from God, and that when correctly used it yields truths, including moral truths, about the world that God has created. Religious beliefs are (generally) not non-rational, or accepted simply based on the declarations of some authority. Christians have always held that their beliefs can survive critical examination. Religiously-grounded moral claims should be subjected to critical scrutiny, and this includes considering whether they have secular support. In other words, Christians should seek to achieve at least some degree of theo-ethical equilibrium. Finding secular corroboration for a religiously-grounded moral belief can increase one's confidence in the claim, help clarify its meaning and implications, and provide extra motivation to abide by it. ${ }^{27}$

It is also plausible that the Christian view of God supports the idea that non-religious individuals are able to live at least minimally moral lives. There is clear empirical support for this; many atheists live in ways that theists recognise as moral. It is also evident that many Christian moral principles do have secular rationales, and have

\footnotetext{
${ }^{26}$ Rawls, Political Liberalism, pp. 386-367.

${ }^{27}$ Audi, 'Liberal Democracy', pp. 13-14.
} 
been endorsed by non-believers. The final six of the Ten Commandments are an example. ${ }^{28}$ This overlap between secular and religious moral sources gives Audi's and Perry's arguments some plausibility.

Some Christians might object that the TEE argument prioritises secular reason over religious sources of truth. Many Christians believe that the Bible is God's authoritative revelation to humankind, and contains no falsehoods. Christians should accept the Bible's teaching even if it conflicts with secular sources of knowledge, rather than judging the veracity of Biblical teaching using secular evidence and reasoning.

This objection is mistaken. Neither Audi nor Perry argue that secular sources of knowledge should be prioritised over religious ones, merely that both should be considered by believers and that each can help illuminate the other. Secular arguments shed light on what the Bible teaches and help believers to interpret Scripture correctly. One can accept the value of theo-ethical equilibrium without rejecting the accuracy of Scripture.

An analogy with scientific evidence is useful here. In Mark 4:31, Jesus says that the mustard seed is the smallest of all the seeds on earth'. An individual who believes that the Bible contains no falsehoods might reasonably conclude from this passage that mustard seeds are the smallest seeds on earth. This is false, however. Orchid seeds, for instance, are smaller. An individual could have several responses when alerted to this. One would be to deny that orchid seeds are smaller than mustard seeds, since the Bible says otherwise. This would clearly be irrational, especially if she is presented with samples of both seeds. Alternatively, she might change her view of the Bible, and conclude that it does contain falsehoods. A more reasonable response, however, would be to re-evaluate the Biblical evidence, by reconsidering her interpretation of Jesus' words. Was Jesus really making the global botanical claim that no seeds in the whole world are smaller than mustard seeds? Probably not. The mustard seed was the smallest seed sown by Jesus' audience of first century Palestinian farmers. Jesus was speaking proverbially, using the example of mustard seeds to make a point about the kingdom of heaven, rather than stating a scientific thesis. One can therefore

\footnotetext{
${ }^{28}$ Honour your father and mother; do not murder; do not commit adultery; do not steal; do not bear false witness; do not covet.
} 
maintain that the Bible contains no falsehoods while also accepting that other seeds are smaller than mustard seeds. Scientific evidence leads Christians to reconsider the Biblical text and interpret passages differently. Importantly, the claim is not that the Bible 'used to mean something else' and modern science has changed its meaning. The claim is that the Bible was always consistent with scientific truth, but certain interpretations of it were mistaken. ${ }^{29}$ Believers seek a rational integration of secular and religious sources of knowledge. Audi and Perry simply argue that Christians should also do this with regard to morality.

Christians should seek theo-ethical equilibrium, and should expect to find secular arguments supporting many of their religiouslygrounded moral views. However, the considerations justifying this are insufficient to warrant Audi's and Perry's conclusion as to how a believer should respond when secular corroboration is not forthcoming. These considerations do not guarantee that all moral truths have secular grounds, so do not justify the conclusion that Christians should doubt every uncorroborated religiously-grounded moral claim. The elements of God's character highlighted by Audi do not entail that God must have ordered the world such that every moral truth can be affirmed by non-Christians; some truths might only be accessible via revelation. God's desire for individuals to have access to moral truth is consistent with God desiring that they gain access to some of those truths by accepting a religious authority that they presently reject. God might even have made certain moral truths only accessible by theological reasoning as a form of apologetic, since this could cause non-believers to be attracted to Christianity, based on its ability to ground attractive moral claims that lack a secular rationale.

Believers can therefore be justified in accepting moral claims despite a lack of secular corroboration. This is particularly so when the religious evidence is strong, such as when religious sources are (relatively) univocal and there are no plausible alternative interpretations of relevant Scriptural passages and church teachings. If there are no plausible secular arguments for a religiously-grounded moral claim then one should reassess one's religious evidence, and consider

\footnotetext{
${ }^{29}$ Another example is interpretations of the creation narrative in Genesis 1-3 that make it consistent with contemporary scientific theories by denying that Genesis teaches that the world was created in a literal six-day period.
} 
whether the claim is adequately justified. Sometimes, in a parallel to the mustard seed case, one might find that other plausible interpretations of Scripture, or of religious traditions, do not make this claim, and one might therefore have good reason to amend one's view. ${ }^{30}$ When this is not the case, however, one can still be warranted in accepting the claim, even with a high degree of confidence, if the religious evidence is sufficiently strong. Sometimes theo-ethical equilibrium can involve continuing to hold a moral belief on religious grounds alone. Further, one's confidence in the belief can remain high enough that one is willing to act politically on the basis of it. To justify restraint, the TEE argument requires the proposition that one's confidence in any moral claim lacking secular corroboration should be lower than is necessary to justify imposing it upon others, since one lacks a sufficient degree of rational justification. The considerations that Audi and Perry highlight do not justify this proposition. Sometimes one's religious rationale can be sufficiently strong that one can continue to endorse a moral claim with a high degree of confidence, even without secular corroboration.

\section{EBERLE'S OBJECTION}

Section II's rejection of the TEE argument for restraint depended on denying that all moral truths necessarily have secular grounds. Eberle claims that the argument would fail even if this were the case. ${ }^{31}$ Even if God has ordered the world such that there are sound secular arguments for all moral truths, this does not guarantee that those secular arguments are considered plausible within 'contemporary experience, ${ }^{32}$ such that we, here and now, believe they can persuade all fully rational citizens in possession of the relevant facts' ${ }^{33}$ Some moral truths might have sound secular rationales that few (if any) individuals within our society accept, because they do not fit with other beliefs and values that most hold.

Eberle's argument centres upon the fact that what can be rationally justified to one unavoidably and ineliminably on testimony. Testimony is a legitimate source of justified beliefs, and it is

\footnotetext{
${ }^{30}$ This is reciprocal. Christians can justifiably adjudicate secular moral disputes using religious evidence.

${ }^{31}$ Eberle, Religious Conviction, pp. 307-322.

32 This is Perry's phrase.

${ }^{33}$ Audi, 'Liberal Democracy', p. 16.
} 
inevitable that many of one's beliefs will be based on it. Most of our beliefs about history, science, and many other areas, are based upon the testimony of people we consider competent authorities, and we lack the time and epistemic resources to check every such belief. Testimony sometimes leads to false beliefs. One can reason flawlessly yet reach mistaken conclusions because one's starting premises include false testimony. Eberle offers Socrates' belief that the sun orbits the earth as an example. ${ }^{34}$ Socrates was rationally justified in believing this, given the scientific background beliefs of his culture. The testimony of competent authorities led him to an incorrect view.

The same can occur with moral beliefs. Which secular moral arguments one perceives as plausible partly depends upon others' testimony. False testimony can skew one's evaluation, such that one fails to endorse what is in fact a sound secular rationale for a moral truth. Therefore, 'to counsel a citizen to doubt religious grounds for which she can't discern adequate secular corroboration is to counsel her to doubt religious grounds for which she can't discern corroboratory support by relying on the secular component of the culture into which she has been socialised'. ${ }^{35}$ In some cases a culture's moral beliefs on an issue will be distorted, so the reason that a religious citizen cannot find secular corroboration for a religiously-grounded moral truth is that her cognitive endowment, particularly the part reliant on others' testimony, inhibits her from discerning the secular justification that in fact exists.

Eberle gives several examples. One concerns a woman who grows up in a society that consistently degrades members of the female gender. ${ }^{36}$ She believes on religious grounds that all humans are equally valuable, but this claim enjoys no secular corroboration within the beliefs of her patriarchal society. Society's hegemonic ideology valorises 'masculine' virtues, gives all positions of power and prestige to men, and socialises children from a young age to affirm women's inferiority. The 'uniform and unambiguous testimony of the morally wise ${ }^{37}$ confirms this prejudice. Eberle argues that citizens in this cognitive environment would reasonably con-

\footnotetext{
${ }^{34}$ Eberle, Religious Conviction, pp. 310-311.

${ }^{35}$ Ibid., p. 314.

${ }^{36}$ Ibid., p. 311.

${ }^{37}$ Ibid., p. 312.
} 
clude on secular grounds that women are less valuable than men, noting 'that some women have found, and do find, themselves in such a situation'. ${ }^{38}$ A moral truth appears to lack secular grounds within this society, due to its cultural distortions. Since we cannot remove individuals' reliance on testimony, those who sincerely attempt to find an adequate secular rationale for a religiously-grounded belief in moral equality will fail to find one, even if one in fact exists.

Sometimes, a religious citizen will be unable to find a plausible secular argument for a religiously-grounded moral claim because that claim is false. But at other times this will be due to cultural distortions. Individuals cannot know which possibility is actualised in each particular case. Since the latter is possible, an apparent lack of secular grounds is not an adequate reason to doubt a moral claim, if it has strong religious support. It may be that the claim is true, and a sound secular rationale exists, but misleading testimony from one's culture causes the apparent lack of secular grounds.

Perry's later version of the TEE argument suggests a possible reply to both my and Eberle's objections. ${ }^{39}$ Perry accepts that a lack of secular corroboration need not cast great doubt upon moral claims that are uncontroversial within one's religious community and tradition. When all Christians agree, one can reasonably conclude that contrary secular evidence is distorted or misleading. Secular evidence becomes more significant when there is disagreement within one's religious community. Christians should subject their beliefs to particularly careful scrutiny when faced with such disagreement. Contemporary secular experience and arguments are essential to adjudicating between rival positions, such as competing Biblical interpretations. Thus, 'this path uses contemporary experience as a helpmate in deciding what the Bible really teaches about the requirements of human well-being, ${ }^{40}$ If the secular evidence overwhelmingly contradicts one's religiously-grounded moral claim and some co-religionists believe the religious evidence supports a contrary claim that enjoys secular corroboration, then one should

\footnotetext{
${ }^{38} \mathrm{Ibid}$

${ }^{39}$ Perry's argument in Religion in Politics is very similar to Audi's. The extra premise discussed here appears in Under God?

${ }^{40}$ Perry, Under God?, p. 67.
} 
doubt one's view, and be 'extremely wary about banning or otherwise disfavouring conduct on the basis of [one's] claim'. ${ }^{41}$

Given the diversity within Christianity, it is unclear how much difference Perry's additional premise makes in practice. Christianity contains a range of opinions on almost every moral issue relevant to legislation. Further, disagreement is particularly likely precisely when a moral claim appears to lack secular grounds. It seems unlikely that a moral claim lacking such grounds in contemporary experience would nonetheless unite the Christian community. The apparent lack of secular grounds will itself lead some to question received interpretations, causing internal disagreement. Perry's extra premise probably does not make restraint obligatory in any fewer cases.

Further, the extra premise might not make the argument more acceptable to Christians. Those who affirm traditional interpretations of religious sources are likely to consider those who reject those interpretations as revisionists, who constantly change their views to reflect contemporary secular beliefs, rather than remaining faithful to religious truth. Traditionalists might reasonably argue that there will always be such revisionists; their presence provides no reason to view an apparent lack of secular corroboration as a greater challenge to religiously-grounded moral beliefs.

This points to a general ambiguity around the idea of disagreement 'within the Christian community'. How large must the dissenting group be? Must it include some religious authorities or scholars? What constitutes the 'Christian community' anyway, given the diversity of Christian denominations? Perry says little about these issues.

Even setting these complications aside, Perry's amendment to the TEE argument is insufficient to rescue it from my or Eberle's objections. Disagreement on a moral issue among believers should indeed lead Christians on all sides to carefully consider their opponents' arguments and re-evaluate their own positions, and this process of reappraisal should include a consideration of secular arguments. Eberle accepts that secular sources should play a role in religious citizens' moral deliberations. But is unclear why disagreement within Christianity should change an individual's attitude to

\footnotetext{
${ }^{41}$ Ibid., p. 79.
} 
that secular evidence. If she remains convinced of her Biblical interpretation, theological reasoning, endorsement of religious authorities, etc., then the fact that some Christians disagree with her does not in itself give any reason to assign more weight to the lack of favourable secular evidence than she should when there is Christian unanimity. She might reasonably believe that dissenting co-religionists have given secular considerations too much weight, and allowed them unduly to influence their Biblical interpretation, such that they have reached false conclusions. If her best reasoning leads her to hold firm to her religiously-grounded moral claim, then she can reasonably conclude that dissenting co-religionists, and non-religious compatriots, are wrong.

\section{NATURAL LAW}

Perry claims that his TEE argument will be especially plausible for those within the Thomist 'natural law' tradition. ${ }^{42}$ The idea that moral truth is discernible by those who do not accept Christian revelation has traditionally been expressed using the doctrine of natural law. Some Christians' views of natural law would lead them to deny Eberle's claim that it is possible for cultures to be so distorted that they lack plausible secular arguments for moral truths. Similarly, they would deny my claim that some moral truths might simply lack adequate secular grounds. The doctrine could thus bolster the TEE argument for restraint. This section therefore examines Christian views of natural law. ${ }^{43}$ My discussion will necessarily be brief, and the arguments indicative rather than comprehensive, but this will be sufficient to show why an appeal to natural law cannot salvage the TEE argument.

The central claim of (traditional) ${ }^{44}$ natural law doctrine is that the 'grounds and norms of moral obligation are built into human nature $^{, 45}$ and available to be grasped by all. God has structured the world such that there is a moral order 'given in the nature of

\footnotetext{
${ }^{42}$ Ibid., p. 67.

${ }^{43}$ For a recent overview, see Stephen Pope, 'Reason and Natural Law', in Gilbert Meilaender and William Werpehowski (eds.), The Oxford Handbook of Theological Ethics (Oxford: Oxford University Press, 2005), pp. 148-167.

${ }^{44}$ The description in this paragraph does not match 'new natural law', discussed in section V.

${ }^{45}$ Nigel Biggar, Behaving in Public: How to Do Christian Ethics (Grand Rapids, Mich.: W.B. Eerdmans Publishing Company, 2011), p. 29.
} 
things, ${ }^{46}$ which can be apprehended by 'natural reason' - by rational reflection on the world and humanity. Humans can, at least in principle, discover all moral truth through reflection on this created order. This includes truth about our moral obligations and about what things are good, valuable, and lead to human flourishing. As Nigel Biggar writes, 'since the created world is ordered, it is therefore comprehensible by rational creatures... And since the created world is ordered for good, what is comprehensible includes goods or forms of flourishing, ${ }^{47}$

\section{A. The High View of Natural Law}

The strongest version of this doctrine holds that Christian revelation adds nothing to the knowledge of moral truth attainable through independent reasoning. Christianity merely provides a distinct motivation to ascertain, and live by, this truth. Christian faith gives fresh impetus to live a moral life, without changing the content of such a life. Thus, 'there is no such thing as a specifically Christian ethic' ${ }^{48}$ John Mahoney's summary of Aquinas's view reflects this: 'Christian revelation contains in its moral teaching no substantial element over and above what is accessible to human reason without revelation... Revelation as such has nothing in matters of moral behaviour to add to the best of human thinking. ${ }^{49}$ Mahoney notes a 'persistent confidence of the [Catholic] Church's moral tradition in the power of human reasoning to identify moral claims through a consideration of man's nature'. 50

This view seems to bolster the TEE argument. ${ }^{51}$ Since moral truth is discernible independent of revelation, all truths relevant to public life have plausible secular rationales. As Patrick Riordan states, the natural law tradition 'conveys a confidence that appropriately non-religious arguments can be found ${ }^{352}$ whenever political coercion

\footnotetext{
${ }^{46}$ Ibid., p. 37.

${ }^{47}$ Ibid., p. 26

${ }^{48}$ Ibid., p. 31

49 John Mahoney, The Making of Moral Theology: A Study of the Roman Catholic Tradition (New York: Oxford University Press, 1987), pp. 107, 109.

${ }^{50}$ Ibid., p. 83

${ }^{51}$ But see Section V.

${ }^{52}$ Patrick Riordan, 'Permission to Speak: Religious Arguments in Public Reason', The Heythrop Journal 45(2) (2004), pp. 178-196, at p. 191.
} 
is required. Laws can be justified by appeal to those arguments, and citizens should not support laws when their only justifications are religious. Indeed, they should be highly suspicious of any moral claims for which they lack secular grounds, since all moral truths have such grounds. Christian revelation does not change the content of morality, so it is likely that moral claims with only religious rationales are false. When united with this understanding of natural law, the TEE argument does appear to provide sufficient reason for restraint. $^{53}$

However, this 'high view' of natural law can be challenged empirically, philosophically, and theologically. Empirically, it is unclear whether it can explain the fact of reasonable pluralism. The idea that under conditions of freedom reasonable individuals will endorse a diverse range of incompatible comprehensive doctrines is central to PRL. Yet if all moral truth is discernible by the right use of reason, then it seems that the correct explanation for pluralism is not the burdens of judgment, to which even the most reasonable are susceptible, but the moral blindness or bad reasoning of those holding incorrect views. ${ }^{54}$

Philosophically, the high view underestimates the extent to which individuals' present belief-value sets shape what appears reasonable and plausible. Many theologians critical of the high view have been influenced by communitarian thinkers on this point. Robert Gascoigne argues that the high view cannot explain the role that historical traditions and cultural interpretations of the meaning and purpose of human existence play within ethics. 'Practical reason makes normative judgments within the horizon of meaning drawn by the meanings and values characteristic of a tradition'. ${ }^{55}$ Reason never functions independently from foundational assumptions and insights formed within particular traditions. This is not to imply that individuals can only ever accept claims that cohere with their tra-

\footnotetext{
${ }^{53}$ There is a slight complication here. This argument assumes that moral truths are accessible without any theological presuppositions. This is certainly the view of the 'new natural lawyers' (see Section V), and some attribute it to Aquinas. However, others claim that Aquinas believed that while revelation is unnecessary for accessing moral truths, certain theological presuppositions are needed. Natural law arguments will not persuade atheists. If this is right, then it is unclear that the high view of natural law is 'secular' in Audi's sense, or that it supports the TEE argument. I assume the former interpretation in the main text.

${ }^{54}$ Robert Gascoigne, The Public Forum and Christian Ethics (Cambridge: Cambridge University Press, 2001), p. 169.

${ }^{55}$ Gascoigne, Public Forum, p. 172, n. 5.
} 
dition. It is simply to point out that one's worldview shapes the force and plausibility of claims. The high view struggles to accommodate this.

Those who are less persuaded of the pervasive effects of traditions on individuals' moral reasoning might reject this objection. However, one need not accept Gascoigne's communitarian-inspired statements in order to agree that rational justification is partly dependent upon one's present beliefs and values, such that sound moral arguments might appear implausible due to one's present evidential set. The perspectival nature of rational justification, which undergirds Eberle's objection to the TEE argument, ${ }^{56}$ is sufficient to cast doubt on the high view of natural law. ${ }^{57}$

Finally, theologically, the high view underestimates the effects of the fall. Christians believe that the world is corrupted due to sin. This includes the distortion of human moral understanding. ${ }^{58}$ Thus, contra the high view, 'sin distorts moral cognition as well as moral motivation'. ${ }^{59}$ There are elements of moral duty that will make little sense to independent human reason. These include the religious or spiritual practices that the Bible sees as necessary for human flourishing. But Biggar claims that Christianity also 'prescribes new norms of action, new duties of conduct ${ }^{60}$ more generally. For example, the high value placed upon forgiveness and compassion within Christian ethics might not be (as) plausible on a non-Biblical worldview.

\section{B. The Low View of Natural Law}

Emphasising the effects of the fall might lead one to a 'low view' of natural law. On this view, secular ethics is deeply distorted by sin and will have little in common with the morality discernible via Christian revelation. Secular ethics is based upon fundamentally mistaken worldviews. Moral reasoning will inevitably go wrong if it does not begin with God's existence and self-disclosure. Christians

\footnotetext{
${ }^{56}$ Eberle explains his view of rational justification, which I broadly accept, in Religious Conviction, pp. $61-63$.

57 This is not to deny that advocates of the high view can offer replies to this, and the previous, objection. However, convincing replies will likely lead to a more moderate view that does not support Perry's argument.

58 Romans 1:18-25.

59 Biggar, Behaving in Public, p. 37.

${ }^{60}$ Ibid., p. 38.
} 
are 'new creations' with 'renewed minds'. ${ }^{61}$ They can know the mind of God and understand moral truth in a way that non-believers simply cannot.

This account clearly rejects the TEE argument. A lack of secular corroboration for a religiously-grounded moral claim provides no reason to doubt that claim. It is less clear what the low view's political implications are, however. There are at least two possibilities.

First, stressing the distinctiveness of Christian ethics might lead one to withdraw from public life. ${ }^{62}$ Christian revelation only has meaning and force for those whose worldview and lives are comprehensively shaped by it. It cannot be made relevant or accessible to non-Christians. Public ethics can only be a perchance agreement among strangers, a minimal and fragile consensus on basic norms such as respect for security. This leads to 'restraint as withdrawal'. Christians should refrain from appeal to religious reasons to justify laws, but not due to an ideal of respect for their compatriots. Restraint instead arises from the impossibility of Christian ethical understanding being intelligibly communicated to the non-religious, or of finding secular paths to its conclusions. This interpretation of the political implications of the low view is in some senses compatible with PRL's duty of restraint, but is not supportive of it. It is compatible in that Christians should not impose their religiouslygrounded moral beliefs on others. But it differs from PRL in not encouraging citizens to seek generally accessible rationales for those beliefs or to engage in constructive deliberation. For public reason liberals, the inaccessibility of religious arguments to non-believers leads to a call for citizens to engage with one another using shared reasons, rather than to withdraw into enclaves formed around their comprehensive doctrines. ${ }^{63}$

A second interpretation of the low view's political implications is that Christians must be faithful to revealed moral truth, which sometimes includes seeking its enactment in law. They should seek to persuade others, but expect revealed moral truths to often appear

\footnotetext{
${ }^{61} 2$ Corinthians 5:17; Romans 12:2.

${ }^{62}$ Gascoigne, Public Forum, pp. 173-176.

${ }^{63}$ This is true for existing PRL views, which endorse participatory deliberative democracy. 'Enclave' PRL, which encourages (some) citizens to withdraw from public life, is a possible position, but not one endorsed within the literature. Further, even that view's similarity with the 'Christian withdrawal' view is accidental, rather than arising from shared values or goals.
} 
implausible to non-Christians. In such cases, all Christians can do is stand up for truth and seek to enact laws that reflect it, even if many lack reasons to accept those laws. This need not be an illiberal view, since it does not imply a rejection of basic rights and freedoms or of democratic decision-making. But it is a rejection of PRL, since laws need not be justified by reasons that every citizen can accept, and citizens are not obligated to provide public reasons or to refrain from supporting laws when they cannot provide such reasons.

The low view of natural law can also be challenged empirically, philosophically, and theologically, however. Empirically, it seems to miss the substantial moral consensus that exists between different comprehensive doctrines. ${ }^{64}$ As David Fergusson notes, we often find 'common ground without common theory'. ${ }^{65}$ While comprehensive doctrines vary greatly in their metaphysical and meta-ethical beliefs, they often overlap on many substantive moral claims.

Philosophically, several theorists, and even theologians influenced by communitarianism, have argued that there can be 'genuine and substantive communication between traditions'. ${ }^{66}$ Gascoigne argues that principles originally arising within a particular comprehensive doctrine can gain relative independence from that doctrine and be intelligible to others. ${ }^{67}$ While the deepest grounds for such principles are found within a particular worldview, others can nonetheless appreciate something of their force. Jürgen Habermas similarly argues that religious insights can be 'translated from the vocabulary of a particular religious community into a genuinely accessible language' ${ }^{68}$

Theologically, this account seems to underplay the fall's effects upon Christians. Christians believe they are saved from sin, so will not face God's judgment for their sins, but also that they are being saved from sin, by being empowered by God to live less sinful lives. This present-tense salvation - sanctification - is ongoing. Christians are still susceptible to distortions in their moral cognition, mistaken Biblical interpretations, and the effects of hubris. Religious moral beliefs can be distorted, not only secular ones.

\footnotetext{
${ }^{64}$ For example, some variant of the 'golden rule' is accepted within many cultures, traditions, and religions.

${ }^{65}$ David Fergusson, Community, Liberalism and Christian Ethics (Cambridge: Cambridge University Press, 1998), p. 158.

${ }^{66}$ Gascoigne, Public Forum, p. 178.

${ }^{67}$ Ibid., pp. 178-179.

${ }^{68}$ Jürgen Habermas, 'Religion in the Public Sphere', p. 10.
} 
Further, Christians believe that God is at work outside the church as well as within it, such that they can learn from non-Christians, including in the domain of morality. As I noted above, Christians can and do accept sound logical and philosophical argumentation, and are rightly influenced by secular reasoning. This is theologically warranted by the belief that the world, though fallen, still reflects God's creative ordering, and that the voice of the Spirit can speak from both inside and outside the church. ${ }^{69}$

Biggar helpfully summarises these theological points:

'The Christian ethicist should expect to find common ethical ground with others. Although sin undoubtedly clouds human apprehension of the moral order that inheres in the world of the one God's creating, its obfuscation outside the church is evidently not absolute. And its de facto sphere of influence inside the church has not yet been brought to an end'. ${ }^{70}$

Christians should reject the low view of natural law, and so listen to non-Christians' moral views and examine secular evidence and arguments.

\section{The Moderate View of Natural Law}

All of this points to a more nuanced, moderate, view of natural law, which holds neither that all moral truth can be discerned through unaided secular reason, nor that most moral truths are discernible only through revelation and lack resonances with secular values. On this view, reflection on human nature can lead to some understanding of what makes for human flourishing, and all humans, despite their sinfulness, are somewhat capable of accurately grasping moral truths. But we cannot know completely what is good and right without the aid of revelation. Theology can both restate 'ethical truths that are often obscured by sinful rationalisation, ${ }^{, 71}$ and reveal ethical truths that are not accessible to fallen natural reason. In the former case, secular arguments for religiously-grounded moral claims may well be available, but might appear implausible within the present cultural context. In the latter case, there may simply be no secular arguments for a moral claim, but this is not a sure sign that the claim is false. Secular moral reasoning is useful in discerning

\footnotetext{
${ }^{69}$ Biggar, Behaving in Public, p. 27.

${ }^{70}$ Ibid., p. 28.

${ }^{71}$ Ibid., p. 37.
} 
moral truth, and individuals should seek coherence between religiously-grounded moral claims and what they take to be the best secular arguments. But individuals can be warranted in accepting moral claims with only a religious justification. Christians should expect to find areas of ethical agreement with others, but should not be surprised if sometimes no agreement is forthcoming. ${ }^{72}$

This view of natural law can avoid the objections I levelled at the previous views. Empirically, it expects both areas of consensus and reasonable pluralism. Philosophically, it allows for the perspectival nature of rational justification and the effects of culture on reasoning, but also is optimistic about the possibility of communication across traditions and of moral insights finding cross-worldview support. Theologically, it acknowledges the effects of the fall both inside and outside the church, and recognises the importance of revelation to ethical deliberation, while also allowing for God's communication to, and through, non-believers.

There are clearly many gradations of 'strength' of natural law theory, rather than three distinct views. But it is probably fair to say that most theologians affirm positions within the 'moderate' camp. For example, consider Karl Barth, one of the twentieth century's most prominent theologians. Barth is known as a critic of 'natural theology'. I outlined one of his central objections above: what is considered 'natural' is always culturally mediated and historically conditioned. Natural law will always at bottom be a cultural construct, offering no reliable basis for knowing right and wrong. 'Barth rejected the idea of an unmediated and unconditioned moral law to which human beings have universal access, even in their fallen state. ${ }^{73}$ Christian ethics 'must begin with God's gracious action in the revelation of God's witness of the gospel and not in Christian virtue, human law, or natural theology. ${ }^{74}$ We cannot achieve clear moral knowledge independent of God's revelation of Himself and His grace in His Son, Jesus, and thus in Scripture.

\footnotetext{
${ }^{72}$ Versions of this 'moderate view' are endorsed in ibid., pp. 41-42; Gascoigne, Public Forum, pp. $178-181$.

${ }^{73}$ George Hunsinger, 'Karl Barth', in John Witte Jr. and Frank S. Alexander (eds.), The Teachings of Modern Christianity on Law, Politics, and Human Nature, Vol. 1 (New York: Columbia University Press, 2006), pp. 352-380, at p. 374.

${ }^{74}$ David Haddorff, Christian Ethics as Witness: Barth's Ethics for a World at Risk (Eugene, Or.: Cascade Books, 2010), p. 106.
} 
Nonetheless, Barth believed that once we understand grace, we can recognise its operation outside the church, as well as within it. Moral perceptions that do not explicitly rely on grace are always profoundly ambiguous, but this does not mean they contain no truth or validity. Indeed, Christian ethics should 'be absolutely open to all that it can learn from general human ethical inquiry, ${ }^{, 75}$ because 'all non-Christian viewpoints have the potential to be secular witnesses to God's grace, and the task of the Christian community is to listen to the witness of these other voices'. ${ }^{76}$ Often 'the Holy Spirit [speaks] the language of common sense'. ${ }^{77}$ According to George Hunsinger, Barth thus 'gave back with one hand much of what he took away with the other. ${ }^{78}$ Christians can find moral and philosophical truths outside Scripture and the church. They should 'annex' these truths, bringing them into their own theologically-grounded worldview. While Barth was an ardent critic of the high view of natural law, his own view was a moderate one. ${ }^{79}$

The moderate view coheres with my earlier discussion of the TEE argument. Eberle's claim that there can be distortions within a culture's secular moral perceptions, such that moral truths seemingly lack plausible secular grounds, would be denied by (some) advocates of the high view but affirmed by adherents of the moderate view. Those adherents would also endorse my claim that while Christians should pursue theo-ethical equilibrium, they need not doubt moral claims that lack secular corroboration, if they have strong religious evidence.

Unfortunately for PRL, the best theological view of natural law fails to provide support for the TEE argument. The moderate view accepts the relevance of secular moral insights to Christians' discernment of moral truth, but also holds that one can have a sufficiently strong religiously-based justification for a moral claim that one can continue to affirm it with a high degree of confidence, even when one lacks plausible secular grounds. Further, there is no reason to believe that this cannot be the case when there is disagreement on

\footnotetext{
75 Karl Barth, Church Dogmatics, Vol. 2 Pt. 2, eds. G.W. Bromiley and T.F. Torrance (Edinburgh: T\&T Clark, 1957), p. 524.

${ }^{76}$ Haddorff, Christian Ethics, pp. 10-11.

${ }^{77}$ Karl Barth, 'Political Decisions in the Unity of the Faith', in his Against the Stream: Shorter Post-War Writings, 1946-1952 (London: SCM Press, 1954), pp. 147-164, at p. 160.

${ }^{78}$ Hunsinger, 'Karl Barth', p. 375.

${ }^{79}$ Although perhaps closer to the low view than some moderate views are.
} 
the claim within the Christian community, contra Perry's later version of the argument. A lack of secular grounds thus does not necessarily provide one with reason for restraint.

\section{REVISITING THE HIGH VIEW AND RESTRAINT}

I have argued that the most plausible view of the relationship between secular reasoning and revelation within Christianity does not support the TEE argument. The high view of natural law has seen a renaissance in recent decades, however, with the emergence of 'new natural law theory', which holds that the moral order is graspable through reflection about practical rationality. ${ }^{80}$ The first principles of practical reason are known in themselves, ${ }^{81}$ and can be used to identify intrinsically valuable basic goods, which form the basis of morality. New natural law theory thus agrees with the traditional high view that moral norms are accessible to all, but has a different understanding of how they are accessed.

This section revisits the relationship between this view of natural law, theo-ethical equilibrium, and restraint, in order to cast doubt on the coherence that Perry suggests exists.

According to the high view, there is a sound secular argument for every moral truth. ${ }^{82}$ To respond to Eberle's examples of cultural distortion, plausible versions of this view must accept that these sound arguments are not always 'obvious' or 'common sense'. Indeed, its advocates ${ }^{83}$ have always accepted that unaided human reason will not in practice find all moral truths, given the effects of sin. Christian revelation is necessary, to bring to light neglected moral truths. Aquinas held both that 'morality is essentially rational conduct, and as such it must be accessible, at least in principle, to human reason and wisdom, ${ }^{84}$ and that 'not all the conclusions of natural law are universally known, and the more one descends from the general to the particular, the more possible it is for reason to be

\footnotetext{
${ }^{80}$ Key figures here include Germain Grisez, John Finnis, and Robert George. For an overview, see Pope, 'Reason and Natural Law', pp. 155-159.

${ }^{81}$ They are 'comprehended immediately when their meaning and reference are understood, and indemonstrable'. Ibid., p. 155.

82 'Morality is a matter of what reasons require, and reasons are inherently intelligible, shared, common'. John Finnis, 'Is Natural Law Theory Compatible with Limited Government?', in Robert P. George (ed.), Natural Law, Liberalism, and Morality (Oxford: Clarendon Press, 1996), pp. 1-26, at p. 3.

${ }^{83}$ Of both the traditional and 'new' versions.

${ }^{84}$ Mahoney, Making of Moral Theology, p. 106.
} 
unduly influenced by the emotions, or by customs, or by fallen nature'. ${ }^{85}$ Thus, as Mahoney explains, 'the purpose of Revelation, so far as morality is concerned, appears to be essentially remedial, not absolutely necessary for man but in practice almost indispensable, ${ }^{86}$ Revelation corrects mistakes that reason would otherwise make, leading one to accept moral truths one would have rejected. One should always then be able to find secular, natural law, arguments for those truths. But those arguments might not appear particularly persuasive or plausible to non-Christians within one's cultural and social context. Perhaps the woman in Eberle's sexist society could endorse a secular argument for female equality that highlights the lack of relevant differences between women and men that could ground inequality. This could be a sound secular argument, despite not appearing plausible to her compatriots.

There are also contemporary examples of secular arguments that are endorsed by natural law theorists but do not appear persuasive within our cultural context. Widely held moral beliefs in our culture justify a (limited) right to abortion. Many Christians believe that foetuses have full human moral status, and thus this is equivalent to granting a right to murder. Some have presented secular arguments for this conclusion, such as that there is no non-arbitrary way to define when a foetus becomes human at any point post-conception. If we believe that newly-born babies have full moral status then we must also believe this about embryos. ${ }^{87}$ Many citizens might find this secular argument unpersuasive, however.

An even more controversial example is John Finnis's argument that all sexual conduct except non-contracepted coitus within heterosexual marriage is immoral. ${ }^{88}$ Finnis argues that marriage the exclusive, permanent, union of a man and a woman - is a basic, intrinsic, human good, with the dual purpose of friendship and procreation. Sexual intercourse is central to marriage, because it 'actualises, expresses and enables the spouses to experience, at all levels of their being, their marriage itself in each of its essential dimensions: friendship and openness to procreation'. ${ }^{89}$ Through it,

\footnotetext{
${ }^{85}$ Ibid., pp. 105-106.

${ }^{86}$ Ibid., p. 107.

${ }^{87}$ Perry, Religion in Politics, pp. 70-71, attributes this argument to The Catholic Bishops of the United States' 1989 'Resolution on Abortion'.

${ }^{88}$ Finnis, 'Is Natural Law', pp. 12-17; John Finnis, 'Marriage: A Basic and Exigent Good', The Monist 91(3-4) (2008), pp. 388-406.

${ }^{89}$ Finnis, 'Marriage', p. 390.
} 
the couple 'experience the reality of their union as spouses, ${ }^{90}$ and their commitment to their marriage and its dual purpose. Nonmarital sex, meanwhile, realises no intelligible good. Indeed, it sets the wills of those who engage in it against the good of marriage, by denying that sex acts should be reserved to the marital kind. Practical reason directs us to the basic good of marriage. Choosing against it, by engaging in non-marital sex, is unreasonable and immoral. ${ }^{91}$

This argument might seem implausible to many. But it is a good example of 'new natural law' argumentation. This demonstrates that those with a high view of natural law do not believe that all moral truths are 'obvious' or 'immediate'. All moral truths are accessible through secular reasoning, but that reasoning can be highly complex and sophisticated. Sometimes, that reasoning is not very 'accessible' to ordinary citizens. Further, natural law theorists offer secular arguments that few, if any, non-Christians accept. Some critics suggest that only those who already endorse the conclusions on religious grounds find new natural law arguments persuasive, ${ }^{92}$ or even that religious presuppositions are implicit within those arguments. ${ }^{93}$

What are the implications of this for the TEE argument, and for PRL more generally? The answer largely turns on whether (new) natural law arguments count as public reasons.

Natural law arguments are secular; they (purportedly) do not rely on religious premises or beliefs for their justificatory force. So they seemingly provide public reasons on Audi's view. Even if they only persuade Christian citizens, who also have religious grounds for the laws in question, this does not prevent natural law arguments from providing public reasons. Audi writes that secular reasons need not actually be shared by everyone; 'they need only be in a certain way accessible to rational adults: roughly, appraisable by them through natural reason in light of facts to which they have access on the basis of exercising their natural rational capacities'. ${ }^{94}$ Arguably, natural law

\footnotetext{
${ }^{90}$ Andrew Lister, Public Reason and Political Community (London: Bloomsbury Academic, 2013), p. 143. pp. 141-150 discuss Finnis's argument in relation to PRL in detail.

${ }^{91}$ Finnis, 'Marriage', pp. 392-393.

92 Greenawalt claims that Finnis's 'argument has resonance almost exclusively among people who happen to accept the conclusions on religious grounds'. Kent Greenawalt, 'What Are Public Reasons?', Journal of Law, Philosophy and Culture 1(1) (2007), pp. 79-105, at p. 102.

${ }^{93}$ Bamforth and Richards, Patriarchal Religion, Chapter 4. Their arguments for this claim strike me as rather weak and unpersuasive. They discuss sexual intercourse on pp. 94-115.

${ }^{94}$ Audi, Democratic Authority, p. 70. I think this marks a shift in Audi's views since his 'Liberal Democracy', but lack space to explore this here.
} 
arguments fulfil this criterion. ${ }^{95}$ If so, then other public reason liberals who characterise public reasons as those accessible to all citizens should also accept that natural law arguments provide such reasons. ${ }^{96}$

On this approach, the high view of natural law coheres with PRL's duty of restraint. Proponents of the high view agree that citizens should not support laws for which their only arguments are religious; natural law arguments are also required. If these arguments provide public reasons, then both the high view and PRL agree that citizens should only support laws for which they have public reasons. ${ }^{97}$

This comes at a high cost for PRL, however. PRL no longer achieves its aim of ensuring that laws are justified by reasons whose normative force can be appreciated by all citizens. Many citizens find natural law arguments to be completely implausible and unpersuasive. ${ }^{98}$ Laws justified by appeal to them do not seem to be justified by reasons that all can reasonably be expected to endorse.

It is important to be clear that the problem here is not simply that natural law arguments are controversial and disputed. This is true for most arguments within public reason. PRL aims not to settle political debates, but to show what their currency should be. ${ }^{99}$ Disagreement over the interpretation and relative weight of values and evidence will remain, but this is unproblematic as long as the right kind of reasons are used to justify laws. However, many find natural law arguments to be not merely inconclusive but as lacking any force whatsoever. This is why their inclusion within public reason seems problematic, from a PRL perspective.

Audi himself writes that coercive laws must be justified in terms of considerations... that any rational adult will find persuasive and can identify with'. ${ }^{100}$ Many natural law arguments do not seem to meet this criterion. So perhaps Audi would rule out, as non-public,

\footnotetext{
95 Audi discusses the relationship between 'secular' and 'natural' reasons in ibid., pp. 76-86, and Robert Audi, 'Natural Reason, Natural Rights, and Governmental Neutrality Toward Religion', Religion and Human Rights 4(2) (2009), pp. 157-175.

${ }^{96}$ Vallier, Liberal Politics, pp. 113-116.

${ }^{97}$ PRL obviously also includes public reasons that are not natural law arguments.

${ }^{98}$ According to Greenawalt, many find that Finnis's position on sexuality is 'not only unpersuasive on balance but that it appeals to an esoteric set of assumptions rather than any common reason'. Kent Greenawalt, 'Natural Law and Public Reasons', Villanova Law Review 47(3) (2002), pp. 531-552, at p. 545.

${ }^{99}$ Rawls, Political Liberalism, pp. 474-476.

${ }^{100}$ Audi, 'Liberal Democracy', p. 16.
} 
secular arguments that no non-religious citizens 'identify with', or recognise as having normative force. Similarly, Perry repeatedly mentions 'contemporary experience' as the source for proper public arguments. Given that most citizens reject natural law arguments, we might judge that they do not draw upon 'contemporary experience' in the requisite way. Indeed, Perry contends that Finnis's argument concerning sex is implausible, so should not be the basis of political action. ${ }^{101}$ Rawls also mentions Finnis's argument, and states that it falls 'outside the domain of the political, ${ }^{, 102}$ and as such does not provide public reasons. Rawls evidently thinks that this argument is not independent of a comprehensive doctrine and/or is not based on ideas implicit in our public political culture. It is thus an example of an argument that is secular yet sectarian. I think most public reason liberals would agree.

If (many) natural law arguments are non-public, however, then Perry is wrong to claim that the high view coheres with his TEE argument. Proponents of the view believe that natural law arguments provide sound, generally accessible, reasons for political action. ${ }^{103}$ While citizens should offer non-religious reasons for laws, and should not support laws for which their only reasons are religious, this understanding of restraint does not match PRL's duty of restraint, if natural law arguments are ruled out as non-public.

It seems, therefore, that the high view of natural law coheres with the TEE argument, and with PRL's duty of restraint, only if one adopts an account of public reasons that most public reason liberals will reject. Even the high view thus does not salvage the TEE argument.

This question of the status of natural law arguments - of whether they provide public reasons - points to a more general problem for PRL: how we define the content of public reason. ${ }^{104}$ What reasons count as 'accessible to', 'acceptable to', or 'capable of being shared by' all citizens? How do we identify which reasons have the relevant

\footnotetext{
${ }^{101}$ Perry, Religion in Politics, pp. 82-96.

${ }^{102}$ Rawls, Political Liberalism, p. 458.

${ }^{103}$ Finnis, 'Is Natural Law'; Robert P. George and Christopher Wolfe, 'Natural Law and Public Reason' in Robert P. George and Christopher Wolfe (eds.), Natural Law and Public Reason (Washington, D.C.: Georgetown University Press, 2000), pp. 51-74.

${ }^{104}$ Greenawalt, 'Natural Law', p. 552, argues that considering the 'status of natural law arguments shows that the boundaries of public reason are very hard to define'. See also Bamforth and Richards, Patriarchal Religion, pp. 31-45.
} 
good-making property? Audi's view that citizens should only support laws for which they have an adequate secular rationale is one attempt at answering this question. As we have seen, however, some Christians might believe that they have an adequate secular rationale based on a natural law argument that few non-Christian citizens find plausible. PRL's main motivation, that laws be justified by reasons all can recognise as having normative force, is not fulfilled in this case. Many other attempts to define 'public reasons' according to those reasons being 'accessible to' or 'shareable by' all citizens face similar problems, as Eberle and Vallier have shown. ${ }^{105}$ My discussion further illustrates these problems.

\section{CONCLUSION}

The TEE argument seeks to show that Christian citizens have good reasons, internal to their religious worldview, to find secular corroboration for religiously-grounded moral claims, to doubt claims that lack such corroboration, and to refrain from supporting laws for which they have only religious reasons. PRL, or at least its major implication for citizens, should thus be accepted by Christians, for theological reasons. Loyalty to God does not conflict with the duty of restraint, because there will always be secular rationales for moral truths, and thus Christians should only support laws when they have such a rationale.

This theological defence of the duty of restraint fails, for several reasons. First, while Christians should seek theo-ethical equilibrium, the considerations supporting this are insufficient to warrant the conclusion that citizens should not support laws for which their only justification is religious, since they do not show that all moral truths have a secular rationale. Second, even if all moral truths do have a secular rationale, this does not guarantee that this rationale appears plausible in one's current cultural context. Third, the most plausible view of natural law - the moderate view - does not support the argument for restraint. Finally, even the high view of natural law does not necessarily cohere with PRL's duty of restraint; a definition of 'public reasons' that creates coherence undermines PRL's main motivation.

\footnotetext{
${ }^{105}$ Eberle, Religious Conviction, pp. 195-293; Vallier, Liberal Politics, pp. 103-124.
} 
One of the central arguments for why Christians should accept the duty of restraint therefore fails, leaving the conflict of loyalty objection intact, and the question of the basis on which Christians can endorse PRL, and thus be part of the overlapping consensus, still unresolved.

\section{ACKNOWLEDGEMENTS}

Thanks to Matthew Anderson, Cécile Laborde, John Perry, Kevin Vallier, Jeremy Waldron, Stuart White, and two anonymous reviewers for this journal for helpful comments. Earlier versions of this paper were presented at the University of Oxford Philosophy of Religion Works in Progress Group and at a conference on religion and public justification at University College London. Thanks to all who attended on those occasions for their questions and feedback, and especially to Christopher Kyle and Aurélia Bardon.

\section{OPEN ACCESS}

This article is distributed under the terms of the Creative Commons Attribution 4.0 International License (http:// creativecommons.org/licenses/ by/4.0/), which permits unrestricted use, distribution, and reproduction in any medium, provided you give appropriate credit to the original author(s) and the source, provide a link to the Creative Commons license, and indicate if changes were made.

\section{REFERENCES}

Audi, Robert, Liberal Democracy and the Place of Religion in Politics. in Audi Robert, and Wolterstorff Nicholas (eds.), Religion in the Public Square: The Place of Religious Convictions in Political Debate, (London: Rowman \& Littlefield, 1997).

Audi, Robert 'Natural Reason, Natural Rights, and Governmental Neutrality Toward Religion', Religion and Human Rights 4(2) (2009): 157-175.

Audi, Robert, Democratic Authority and the Separation of Church and State (New York: Oxford University Press, 2011).

Bamforth, Nicholas C., and Richards, David A.J., Patriarchal Religion, Sexuality, and Gender: A Critique of New Natural Law (Cambridge: Cambridge University Press, 2008).

Barth, Karl, Church Dogmatics, Vol. 2 Pt. 2, eds. G.W. Bromiley and T.F. Torrance (Edinburgh: T\&T Clark, 1957).

Barth, Karl, 'Political Decisions in the Unity of the Faith', in his Against the Stream: Shorter Post-War Writings, 1946-1952 (London: SCM Press, 1954).

Biggar, Nigel, Behaving in Public: How to Do Christian Ethics (Grand Rapids, MI: W.B. Eerdmans Publishing Company, 2011). 
Eberle, Christopher J, Religious Conviction in Liberal Politics (Cambridge: Cambridge University Press, 2002).

Fergusson, David, Community, Liberalism and Christian Ethics (Cambridge: Cambridge University Press, 1998).

Finnis, John, Is Natural Law Theory Compatible with Limited Government?. in George Robert P (eds.), Natural Law, Liberalism, and Morality, (Oxford: Clarendon Press, 1996) pp. 1-26.

Finnis, John 'Marriage: A Basic and Exigent Good', The Monist 91(3-4) (2008): 388-406.

Gascoigne, Robert, The Public Forum and Christian Ethics (Cambridge: Cambridge University Press, 2001).

George, Robert P., and Wolfe, Christopher, 'Natural Law and Public Reason' in George, Robert P. and Wolfe, Christopher (eds.), Natural Law and Public Reason (Washington, D.C.: Georgetown University Press, 2000), pp. 51-74.

Greenawalt, Kent 'Natural Law and Public Reasons', Villanova Law Review 47(3) (2002): 531-552.

Greenawalt, Kent 'What Are Public Reasons?', Journal of Law, Philosophy and Culture 1(1) (2007): 79-105. Habermas, Jürgen 'Religion in the Public Sphere', European Journal of Philosophy 14(1) (2006): 1-25.

Haddorff, David, Christian Ethics as Witness: Barth's Ethics for a World at Risk (Eugene, OR: Cascade Books, 2010).

Hunsinger, George, 'Karl Barth', in Witte Jr., John and Alexander, Frank S. (eds.), The Teachings of Modern Christianity on Law, Politics, and Human Nature, Vol. 1 (New York: Columbia University Press, 2006), pp. 352-380.

Laborde, Cécile, Justificatory Secularism. in D’Costa Gavin, Evans Malcolm, Modood Tariq, and Rivers Julian (eds.), Religion in a Liberal State, (Cambridge: Cambridge University Press, 2013).

Lister, Andrew, Public Reason and Political Community (London: Bloomsbury Academic, 2013).

Lott, Micah 'Restraint on Reasons and Reasons for Restraint: A Problem for Rawls's Ideal of Public Reason', Pacific Philosophical Quarterly 87(1) (2006): 75-95.

Mahoney, John, The Making of Moral Theology: A Study of the Roman Catholic Tradition (New York: Oxford University Press, 1987).

Perry, Michael J, Religion in Politics: Constitutional and Moral Perspectives (Oxford: Oxford University Press, 1997).

Perry, Michael J, Under God? Religious Faith and Liberal Democracy (Cambridge: Cambridge University Press, 2003).

Peter, Fabienne 'Epistemic Foundations of Political Liberalism', Journal of Moral Philosophy 10(5) (2013): 598-620.

Pope, Stephen, Reason and Natural Law. in Meilaender Gilbert, and Werpehowski William (eds.), The Oxford Handbook of Theological Ethics, (Oxford: Oxford University Press, 2005) pp. 148-167.

Rawls, John, Political Liberalism, expanded edition (New York: Columbia University Press, 2005).

Riordan, Patrick 'Permission to Speak: Religious Arguments in Public Reason', The Heythrop Journal 45(2) (2004): 178-196.

Swan, Kyle 'Can a Good Christian be a Good Liberal?', Public Affairs Quarterly 20(2) (2006): 163-173.

Vallier, Kevin, Liberal Politics and Public Faith: Beyond Separation (Oxford: Routledge, 2014).

Wolterstorff, Nicholas, The Role of Religion in Decision and Discussion of Political Issues. in Audi Robert, and Wolterstorff Nicholas (eds.), Religion in the Public Square: The Place of Religious Convictions in Political Debate, (London: Rowman \& Littlefield, 1997).

Christ Church, University of Oxford,

St Aldates, Oxford, OX1 1DP, UK

E-mail: paul.billingham@chch.ox.ac.uk 